\title{
YHWH's "Greatness," "Mighty hand," "Deeds" and "Mighty Acts" in Deuteronomy 3:24 ALBERT COETSEe (NORTH-WEST UNIVERSITY)
}

\begin{abstract}
This article investigates the four words or phrases used in Deut 3:24 to describe the uniqueness of YHWH, namely "greatness" (גדi),

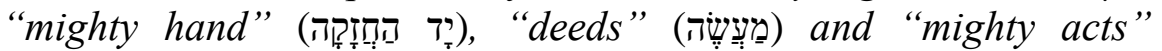

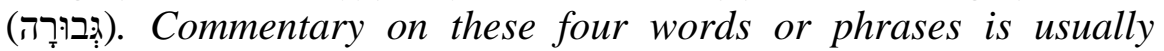
limited to a brief discussion of their possible referential background. Virtually no attempt is made to distinguish between the meanings of these words. Secondly, little conclusive proof is provided for the assumed referential background of the words, and thirdly, scholars are silent on the distinctive contribution of Deut 3:24 to Deuteronomy's overall theme of the uniqueness of YHWH. This article aims to address these three lacunae.
\end{abstract}

KEYWORDS: Deuteronomy 3:23-29, Deuteronomy 3:24,

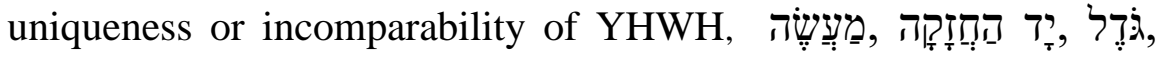
גִּבוּרָה

\section{A INTRODUCTION}

The uniqueness or incomparability of YHWH is a primary theme in the book of Deuteronomy (cf. 4:35, 39; 6:4; 10:17; 32:12, 17, 39; 33:26). ${ }^{1}$ The first explicit reference to this theme is found in Moses' fervent prayer to enter the Promised Land in Deut 3:23-29. Preceding his petition, Moses prays:

* Submitted: 13/08/2020; peer-reviewed: 08/12/2020; accepted: 11/12/2020. Albert Coetsee, "YHWH's "Greatness," "Mighty Hand," "Deeds" and "Mighty Acts" in Deuteronomy 3:24," Old Testament Essays 34 no. 1 (2021): 114 - 140. DOI: https://doi.org/10.17159/2312-3621/2021/v34n1a8.

This paper was initially written for and presented at the e-Conference "Deuteronomy Today: Memory and Transmission, Then and Now" hosted by the South African Theological Seminary 2-3 April 2020.

1 The seminal study on the incomparability of uniqueness of YHWH in the Old Testament, including Deuteronomy, is the monograph of Casper J. Labuschagne, The Incomparability of Yahweh in the Old Testament (Leiden: Brill, 1966). One of the most comprehensive recent studies on the uniqueness or incomparability of YHWH in relation to monotheism in Deuteronomy, is the monography of Nathan MacDonald, Deuteronomy and the Meaning of Monotheism (2d ed.; Tübingen: Mohr Siebeck. 2012). 
"O Lord GoD, you have only begun to show your servant your greatness and your might; what god in heaven or on earth can perform deeds and mighty acts like yours!" (Deut 3:24)

Four words or phrases are used in this praise to describe the uniqueness

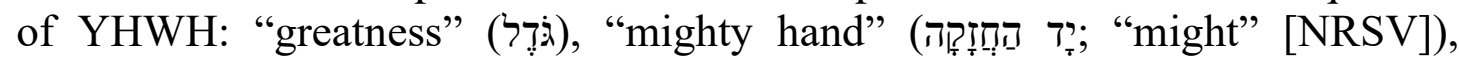

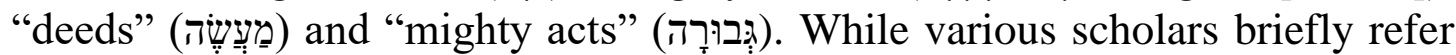
to the possible referential background of these words, ${ }^{3}$ this is almost the only

\footnotetext{
${ }^{2}$ All quotations from the Bible are from the NRSV. References to chapters and verses of biblical books, however, are from the Hebrew Bible.
}

3 Various scholars briefly link the description found in Deut 3:24 to specific events in the life of Moses. Most link it to the exodus. See among others Peter C. Craigie, The Book of Deuteronomy (New International Commentary on the Old Testament; Grand Rapids: Eerdmans, 1976), 126, Moshe Weinfeld, Deuteronomy 1-11: (Anchor Bible; New York: Doubleday, 1991), 191, Eckart Otto, Deuteronomium 1,1-4,43 (Herders Theologischer Kommentar zum Alten Testament; Freiburg im Breisgau: Herder, 2012), 502 (by means of comparison with Deut 9:26) and Jack R. Lundbom, Deuteronomy: A Commentary (Grand Rapids: Eerdmans, 2013), 225. Jeffrey H. Tigay, The JPS Torah Commentary: Deuteronomy (Philadelphia: Jewish Publication Society, 1996), 39, apart from the exodus events, also mentions Mount Sinai as possible background. In the same vein, Lundbom, Deuteronomy, 225, links these words to both the exodus and the wilderness wanderings. Craigie, Deuteronomy, 126 also briefly mentions the possibility of the conquest of the lands east of the Jordan as background, while Weinfeld, Deuteronomy, 191 and Lundbom, Deuteronomy, 225226 also refer to the triumph over Sihon the king of Heshbon and Og the king of Bashan. J. Gordon McConville, Deuteronomy (Apollos Old Testament Commentary; Leicester: Apollos, 2002), 95 and Christopher J.H. Wright, Deuteronomy (New International Biblical Commentary; Peabody: Hendrickson Publishers, 1996), 41 take a more general route by referring respectively to "Moses' own participation in the events," which showed YHWH's unique power and "the incredible acts of God in two generations." Finally, a number of scholars are silent on the matter. See among others Eugene H. Merrill, Deuteronomy (The New American Commentary; Nashville: Broadman \& Holman, 1994), 110-111; Walter Brueggemann, Deuteronomy (Abingdon Old Testament Commentaries; Nashville: Abingdon Press, 2001), 45; Duane L. Christensen, Deuteronomy 1:1-21:9 (Word Biblical Commentary; Nashville, TN: Thomas Nelson Publishers, 2001), 68-69 and Daniel I. Block, Deuteronomy (The NIV Application Commentary; Grand Rapids: Zondervan, 2012), 104-105. The chosen methodology for the present study is synchronic in nature and thus excludes aspects pertaining to a more religious-historical nature, like the work of Rainer Albertz, A History of Israelite Religion in the Old Testament Period (2 vols.; trans. J. Bowden; London: SCM Press, 1994). These aspects are indeed interesting and important, as are issues of a more theological nature related to the use of these words in related (i.e. Deuteronomistic History) as well as other parts of the Old Testament. See for example Walter Brueggemann, Theology of the Old Testament: Testimony, Dispute, Advocacy (Minneapolis: Fortress Press, 1997), and John 
commentary provided on these words. Consequently, three lacunae can be identified. First, virtually no attempt is made to distinguish between the meanings of these words. Secondly, little conclusive proof is provided for the assumed referential background of these words. ${ }^{4}$ Thirdly, scholars are silent on the distinctive contribution of Deut 3:24 to Deuteronomy's overall theme of the uniqueness of YHWH. This article aims to address all three lacunae.

The discussion to follow starts by giving an overview of the literary and historical context of Deut 3:24, briefly commenting on the content of the passage. Next, the four words or phrases used in Deut 3:24 to describe the uniqueness of YHWH are investigated in detail in order to distinguish them from one another, and as part of a preliminary deduction of various possibilities concerning the referential background of each. This is followed by a synthesis of the findings in order to confirm the referential background of the words. Finally, the article concludes by reflecting on the distinctive contribution of Deut 3:24 to Deuteronomy's overall theme of the uniqueness of YHWH.

\section{B CONTEXT AND CONTENT OF DEUT 3:24}

In Deut 1:1-3:29, which is part of the first speech of Moses (Deut 1:1-4:43), "Moses gives a historical overview of the events of the past forty years" to the people "standing on the brink of entering the Promised Land." $3: 23-29$, which can easily be identified as a pericope from its content and the markers in the Hebrew text, ${ }^{6}$ is the final passage within this overview. Structurally, this passage forms the conclusion to Moses' historical overview before the climax of his first speech is reached in Deut 4:1-40, in which Moses exhorts the present generation to obey YHWH wholeheartedly.

Deuteronomy 3:23-29 contains Moses' passionate plea to YHWH to allow him to enter and see the Promised Land (3:24-25), and YHWH's answer (3:26-28). The passage is framed by indications of time (3:23) and space $(3: 29){ }^{7}$

Goldingay, Old Testament Theology (3 vols.; Downers Grove, IL: Intervarsity Press, 2003-2009). However, these fall outside the scope of the current study.

4 In this article, "referential background" is used to refer to the historical events the words employed (in Deut 3) point to.

5 Albert Coetsee, "YHWH and Israel in Terms of the Concept of Life in Deuteronomy," OTE 32/1 (2019):105. This is the case if the text is taken in its present form, namely as prior to the conquest of the Promised Land. For discussion of the possible redactional layers and the dating of Deut 3:23-29, see Otto, Deuteronomium, 500-505.

6 See the setumah at the end of Deut 3:22, and the petuhah at the end of Deut 3:29.

7 Cf. Otto, Deuteronomium, 499 who views 3:23 and 3:29 as "Rahmen." 
The background of this prayer is the events at the waters of Meribah, recorded in Num 20:1-13. The people quarrelled with Moses because of the lack of water and other resources. In answer to this, Moses was commanded by YHWH to tell a rock to yield its water. Instead, Moses asked the assembled people if he and Aaron should bring water out of the rock, and then (presumably in frustration) struck the rock twice with his staff. Though water came out abundantly, YHWH reprimanded Moses and Aaron for their conduct:

"Because you did not trust in me, to show my holiness before the eyes of the Israelites, therefore you shall not bring this assembly into the land that I have given them." (Num 20:12)

Moses' $\sin$ seems to be that he struck the rock instead of speaking to it, ${ }^{8}$ although the exact nature of his sin is a matter of debate among scholars. ${ }^{9}$

In Deut 3:23-29, some time has passed since the tragic events of Meribah. Deut 3:23 refers to Moses pleading with YHWH "at that time" ( הत) , which, viewed in the immediate context, refers to a moment in time after the defeat of Sihon the king of Heshbon and Og the king of Bashan (cf. Deut 2:26-3:22). This triumph over the enemy seems to have renewed Moses' desire to enter the Promised Land. ${ }^{10}$ Moreover, from experience, Moses has learned that "through the effectual fervent prayer of a righteous person, God's disposition may be changed" (cf. Exod 32:11-14; Num 14:13-20). ${ }^{11}$ This is what he hopes for in Deut 3 by pleading with YHWH.

Moses' plea starts with a vocative followed by a declaration of YHWH's uniqueness or incomparability (Deut 3:24). By means of a rhetorical question,

8 Thomas W. Mann, “Theological Reflections on the Denial of Moses," JBL 98/4 (1979):483.

9 The problem lies on two fronts. The first is the nature of Moses' sin in Num 20:11-12, which various scholars argue is not clear. Wright, Deuteronomy, 41-42, could be taken as an example, arguing that Moses "failed in some unspecified way to uphold God's holiness among" the people [my emphasis, A.J.C.]. The second difficulty has to do with some differences between texts referring to Moses' denial of entering the Promised Land (cf. Num 27:12-14; Deut 1:37; 4:21; 32:48-52). Among others, Num 20:12 seems to indicate that Moses' exclusion is his own fault, while Moses states in Deut 1:37 and 3:26 that it is the people's fault. There are various ways of approaching these differences: (1) attempts can be made to harmonise the differences; (2) the differences can be explained as a reflection of different traditions (e.g. deuteronomic vs priestly source); (3) Moses can be blame shifting in Deuteronomy. For some explanations for Moses' denial of entering the Promised Land, see Tigay, Deuteronomy, 425 and especially Mann, "Theological Reflections," 481-494.

10 Tigay, Deuteronomy, 38. Cf. Block, Deuteronomy, 104.

11 Block, Deuteronomy, 111. 
Moses insists that no god in heaven or on earth (a merism) can do what YHWH has done. Blended with these descriptions of YHWH's uniqueness Moses subtly and tactfully tries to convince YHWH to change his mind about his nonentry of the Promised Land. This Moses does masterfully by expressing his conviction that YHWH has only "begun" (ָָכָלד) in the hip 'il, derived from the

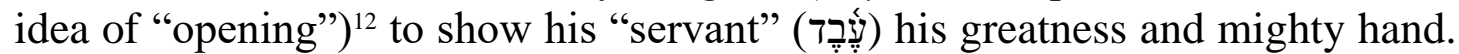
This is followed by the explicit plea in verse 25 to YHWH to "please" (נָ) allow him to go over and see the Promised Land, which Moses, keeping to his

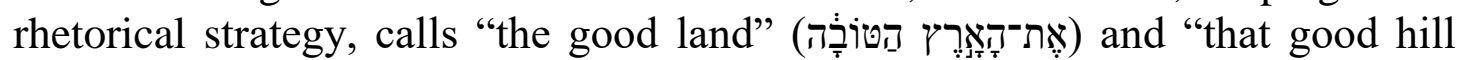

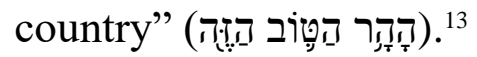

YHWH, however, refuses. Moses states that YHWH became furious

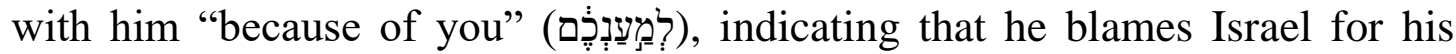
predicament (cf. Deut 1:37). YHWH forbids Moses to speak on the matter again, ${ }^{14}$ but does grant the second part of his plea by allowing him to go up to the top of Pisgah to "see" (רָָָה) the Promised Land. In addition to this, Moses had to charge, encourage and strengthen Joshua, who would lead the people into the Promised Land, indicating that the conquest would continue despite the absence of Moses. The passage ends somewhat abruptly in verse 29 with a geographical reference providing some historical background. ${ }^{15}$

The key concepts of the passage are the verbs רָָָ ("to see") and ("to pass over," or with the secondary and rare use of the verb [in the hitpa 'el], "to become furious"). ${ }^{17}$ Both verbs are found four times in this short passage-

12 F. H. Wilhelm Gesenius and Samuel P. Tregelles, Gesenius' Hebrew and Chaldee Lexicon to the Old Testament Scriptures (Bellingham: Logos Bible Software, 2003), 281 and Francis Brown, Samuel R. Driver and Charles A. Briggs, Enhanced BrownDriver-Briggs Hebrew and English Lexicon (Oxford: Clarendon Press, 1977), 320.

13 Block, Deuteronomy, 105, however, is correct when he states that these words reflect Moses' great respect for YHWH, and are not mere flattery. Nonetheless, Moses' plea does seem to be purposefully structured to venture for a favourable answer.

14 The adverb yi seems to imply that Moses pleaded continually. See Craigie, Deuteronomy, 127 and Christensen, Deuteronomy, 69.

15 For the importance of taking this and other geographical references in the passage into account for interpreting the prayer, see Daniël F. O'Kennedy, "Prayer in Moab (Dt 3:23-29): The Relationship between the Recorded Prayer and Its Historical Geographical Setting," OTE 11/2 (1998): 288-305. Cf. Tigay, Deuteronomy, 40.

16 G.B. Struthers, "עָׁברָ" NIDOTTE 3:317 indicates that the etymology of this secondary use of the verb is uncertain. In Deut 3:23-29, the difference of meaning forms a nice little word play. Moses begs to go over to the Promised Land (עָכָר), but YHWH gets furious (עָבָר). Christensen, Deuteronomy, 67 views this word play as portraying "a whimsical sense of humor."

17 These key concepts are also noted by Christensen, Deuteronomy, 66-67. Tigay, Deuteronomy, 38 indicates that the root עבזה is a leitmotif in Deut 2-3. To the verb 
Moses states that YHWH has only begun to show him his uniqueness $(3: 24)$ and therefore prays to go over and see the Promised Land (3:25). In reaction, YHWH becomes furious (3:26) with Moses, and commands him to go up to the top of Pisgah to see the Promised Land, knowing that he will not go over to it (3:27). Joshua, on the other hand, will go over and lead the people to take possession of the land that Moses will see (3:28).

For the purposes of this study, it should be noted that Moses' declaration in Deut 3:24 that YHWH has only begun to show him his uniqueness forms part of the main argument of the passage.

\section{WORDS DESCRIBING YHWH IN DEUT 3:24}

As indicated above, four words or phrases are used in Moses' prayer to

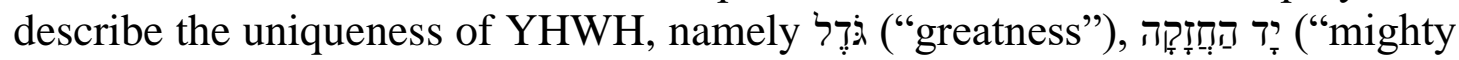

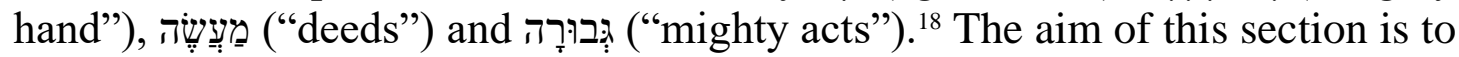
distinguish between the meanings of these words and to deduce various possibilities concerning the referential background of each. Since this is the primary aim of the study, the bulk of the article is devoted to this endeavour.

The meaning of each word or phrase is determined by,

- providing an overview of the occurrence and use of the root and/or word or phrase in the Hebrew Bible according to Hebrew dictionaries;

- doing an independent analysis and categorisation of how the root and/or word or phrase is employed in Deuteronomy;

- comparing similar usages of the word or phrase in the Hebrew Bible; and

- concluding (in the light of all the data) what the specific nuance of the word or phrase is in Deut 3:24.

should be added the two occurrences of the noun ("eyes"; 3:272), and to the verb

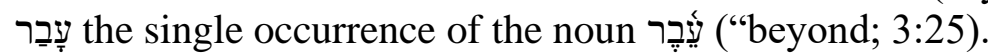

18 Deuteronomy 3:24 in the LXX contains six words or phrases to describe the

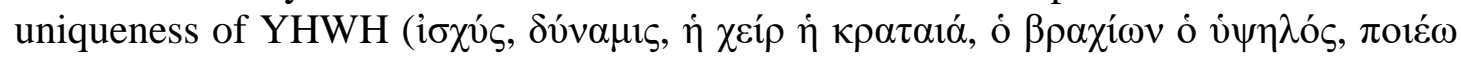

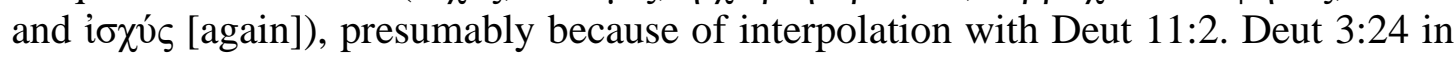
the Peshitta also contains an additional phrase, namely uplifted/exalted arm"). The current article, however, focuses on and investigates the use of the four Hebrew words or phrases in the MT. 


\section{1 לד̧ ("greatness")}

1a Overview of the occurrence and use of גדל in the Hebrew Bible

With roughly 670 occurrences in the MT, ${ }^{19}$ the Hebrew root גדל is one of the most common roots found in the Hebrew Bible. The root forms the basis of the

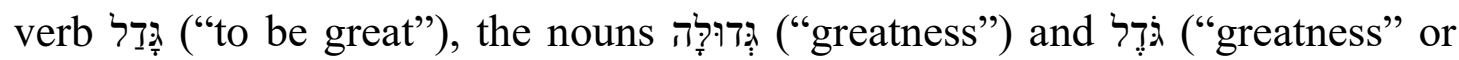
"great deeds"), the adjectives personal names. By far the most frequent occurrences of the root are found in

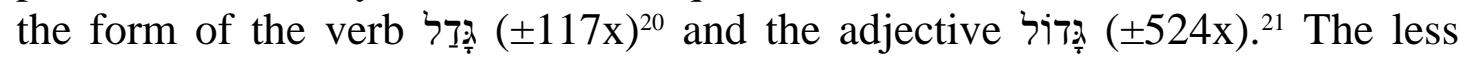

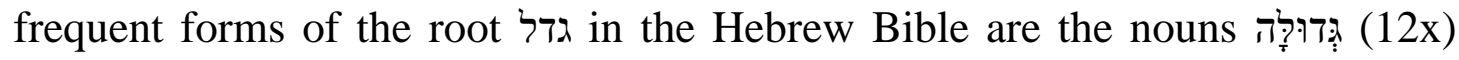
and $(13 \mathrm{x})$, and the adjective

For the purposes of this study, closer investigation of the adjective לais and the noun

- The adjective לiד is is usually rendered as "great," and in reference to persons or things, it largely corresponds to the use of the English equivalent. ${ }^{22}$ It "can be connected with very different concepts." ${ }^{23}$ Most often, it "describes the size or magnitude of the word it modifies." 24 Among others, the adjective is used with abstract terms (like "great things" or "great signs"), as a description of prominence or importance of men or God, as a description of an emotion or phenomenon and as reference to loudness, the devastation of war, and age or status (e.g. "older," "younger"). ${ }^{25}$

- The noun גid is used to refer to "greatness" as attribute in a positive or negative sense. ${ }^{26}$ When referring to God, it refers to his "greatness" or "magnificence," 27 especially as "manifested in his historical acts." 28

19 This total is reached by adding the number of occurrences of the verb, nouns and

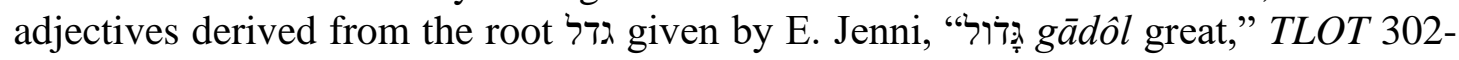

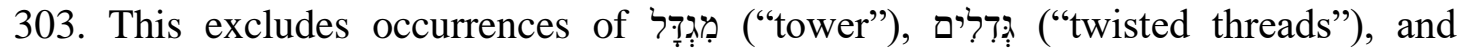

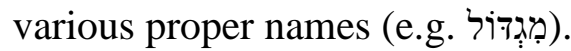

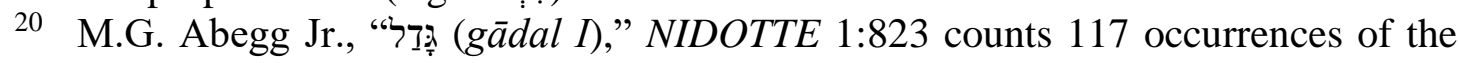

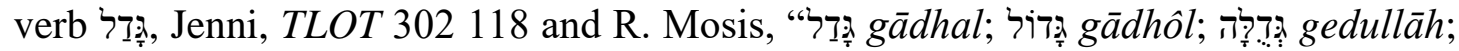

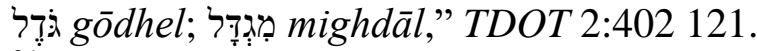

21 Abegg, NIDOTTE 1:823 gives the count as 524, while Jenni, TLOT 302 gives it as 525. Mosis, TDOT 2:392 gives a relative number by stating that the adjective occurs a little over 520 times in the Hebrew Bible.

22 Jenni, TLOT 303.

23 Mosis, TDOT 2:392.

24 Abegg, NIDOTTE 1:824.

25 Cf. Ibid., 1:824-826.

26 Although the concept "attribute" can be an anachronistic misnomer in Old Testament studies, it is used in this article for the sake of discussion.

27 Jenni, TLOT 304. Cf. Abegg, NIDOTTE 1:826. 
When applied to man, it is used in a negative sense (in combination with לברב ) to refer to "pride," "arrogance" or "insolence" (Isa 9:8; 10:12). ${ }^{29}$

1b Analysis and categorisation of גדל in Deuteronomy

Two of the five forms of the root גדל גלול are found in Deuteronomy, namely the

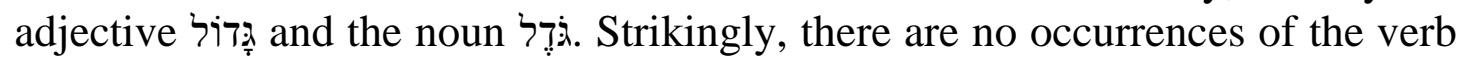
ל times in the book ( $\pm 8 \%$ of the total occurrences in the MT). This is the second largest concentration of the adjective in a single biblical book. ${ }^{30}$ Moreover, five of the thirteen occurrences of the noun i̦̦ in the Hebrew Bible are found in Deuteronomy $( \pm 38 \%)$, by far the most of any biblical book. An overview of the occurrence of these words in Deuteronomy can be seen in Table 1.

\begin{tabular}{|c|c|c|}
\hline 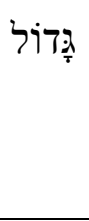 & $44 x$ & $\begin{array}{l}1: 7,17,19 ; 1: 28^{2} ; 2: 7,10,21 ; 4: 6,7,8,32,34,36,37,38 \\
5: 22,25 ; 6: 10,22 ; 7: 19,21,23 ; 8: 15 ; 9: 1^{2}, 2,29 ; 10: 17,21 ; \\
11: 7,23 ; 18: 16 ; 25: 13,14 ; 26: 5,8 ; 27: 2 ; 28: 59 ; 29: 2^{2}, 23,27 \\
34: 12\end{array}$ \\
\hline 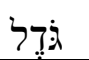 & $5 x$ & $3: 24 ; 5: 24 ; 9: 26 ; 11: 2 ; 32: 3$ \\
\hline
\end{tabular}

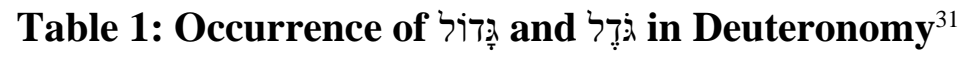

A closer investigation reveals that the adjective used in eleven different ways in Deuteronomy, of which a summary can be seen in Table 2.

28 Mosis, TDOT 2:400.

29 Cf. Brown, Driver and Briggs, Enhanced Lexicon, 152.2 and Gesenius and Tregelles, Hebrew and Chaldee Lexicon, 159.

30 Cf. Jenni, TLOT 302-303.

31 All tables in this article are my own composition, compiled with the help of Gerhard Lisowsky, Konkordanz zum Hebräischen Alten Testament (Stuttgart: Privilegierte württembergische Bibelanstalt, 1958) and the search function of Logos Bible Software. In the current table, the count of 44 occurrences of the adjective in Deuteronomy is supported by Jenni, TLOT 302 and Lisowsky, Konkordanz, 308. 
122 Coetsee, "YHWH's Greatness," OTE 34/1 (2021): 114-140

\begin{tabular}{|c|c|c|c|}
\hline & & 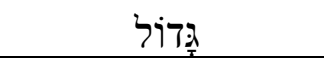 & גִִָּל \\
\hline Geographical descriptions & $4 x$ & $1: 7,19 ; 2: 7 ; 8: 15$ & \\
\hline Social status & $1 \mathrm{x}$ & $1: 17$ & \\
\hline The cities in the Promised Land & $3 x$ & $1: 28^{\mathrm{b}} ; 6: 10 ; 9: 1^{\mathrm{b}}$ & \\
\hline The people of the Promised Land & $7 x$ & $\begin{array}{l}1: 28^{\mathrm{a}} ; 2: 10,21 \\
4: 38 ; 9: 1^{\mathrm{a}}, 2 \\
11: 23\end{array}$ & \\
\hline The people of Israel & $4 x$ & $4: 6,7,8 ; 26: 5$ & \\
\hline An attribute of God & $7 x$ & $7: 21 ; 10: 17$ & $\begin{array}{l}3: 24 ; 5: 24 ; \\
9: 26 ; 11: 2 ; 32: 3\end{array}$ \\
\hline God's activity at the exodus & $12 \mathrm{x}$ & $\begin{array}{l}4: 32,34,37 ; \\
6: 22 ; 7: 19 ; \\
9: 29 ; 10: 21 ; \\
11: 7 ; 26: 8 ; \\
29: 2^{\text {ab }} 34: 12\end{array}$ & \\
\hline God's activity at Sinai & $4 x$ & $\begin{array}{l}4: 36 ; 5: 22,25 \\
18: 16\end{array}$ & \\
\hline God's judgment & $4 x$ & $\begin{array}{l}7: 23 ; 28: 59 \\
29: 23,27\end{array}$ & \\
\hline Weights and measures & $2 \mathrm{x}$ & $25: 13,14$ & \\
\hline Signs of remembrance & $1 \mathrm{x}$ & $27: 2$ & \\
\hline
\end{tabular}

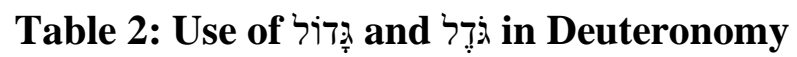

For the purpose of this study, four of these eleven different employments of

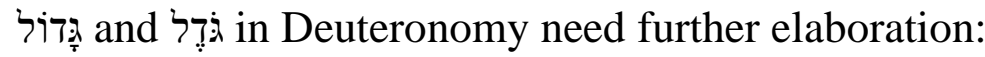

- An attribute of God: "Greatness" is depicted as an attribute of God, shown to both Moses (3:24) and the people of Israel (5:24), and made especially visible in the redemption from Egypt (9:26; 11:2). Consequently, God is called a "great God" (7:21; 10:17), and "greatness" is ascribed to him (32:3).

- God's activity at the exodus: While God's activity at the exodus is described in a variety of ways in the book of Deuteronomy, the coupling of the exodus and the word-group "great" is striking. It is said that the 
exodus was accompanied by "terrifying (lit. great) displays of power" (4:34; 26:8; specifically done through Moses as agent [34:12]), "great signs and wonders" $\left(6: 22 ; 29: 2^{\mathrm{b}}\right)$ and "great trials" $\left(7: 19 ; 29: 2^{\mathrm{a}}\right)$. God brought them out of Egypt with his "great power" (4:37; 9:29). Together with the wilderness period, the exodus is called God's "great deed" (11:7) - a period in which they saw the "great [and awesome] things" God did (10:21). What God has achieved with the exodus is called "great" (4:32).

- God's activity at Sinai: At Sinai, the people of Israel saw God's "great fire" (4:36) and they heard God's "loud (lit. great) voice" (5:22), both of which they feared would lead to their death $(5: 25 ; 18: 16)$.

- God's judgment: Four references to God's judgment as "great" are found in Deuteronomy. On the one hand, Moses explains to the people that God will throw the inhabitants of the Promised Land into "great panic" with the conquest $(7: 23)$. On the other hand, Moses warns the people of Israel in the elaboration of the curses associated with covenant disobedience that they can expect "lasting (lit. great) afflictions" (28:59), YHWH's “fierce (lit. great) anger" (29:23) and being uprooted from their land in his "great wrath" (29:27).

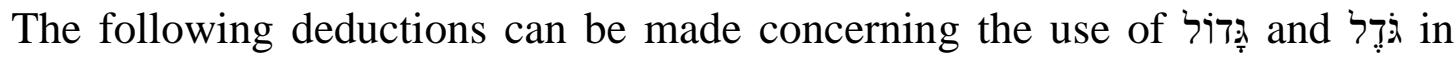
Deuteronomy:

- The majority of references to לִד or 27 of the 49 occurrences $[ \pm 55 \%])$ are used to refer to the attribute of God's greatness or activities that reveal his greatness. In other words, the majority of references to "great" in Deuteronomy are used to refer to who God is and what he does.

- The noun לד̦ is solely used in Deuteronomy to describe the attribute of God's greatness. Four of the five occurrences of $37 \mathfrak{i}$ are used to refer to his "greatness" ( $3: 24 ; 5: 24 ; 9: 26 ; 11: 2)$ while in the Song of Moses, the people "ascribe" (יָָב) greatness to their God (32:3). Where the adjective לita is used to describe the attribute of God's greatness, it describes God's greatness attributively, either stating that he is "a great and awesome God" (7:21) or "the great God, mighty and awesome" (10:17).

- Almost two-thirds of all references to tiדa and ḥִ in Deuteronomy occur in passages that refer to the exodus $(16 \mathrm{x} ; \pm 33 \%)^{32}$ and the conquest of the Promised Land $(15 \mathrm{x} ; \pm 31 \%){ }^{33}$ This is striking, although unsurprising

32 Deuteronomy 3:24; 4:32, 34, 37; 6:22; 7:19; 9:26, 29; 10:17, 21; 11:2, 7; 26:8; 29:2ab; 34:12.

33 Deuteronomy $1: 7 ; 2: 21 ; 4: 6,7,8,38 ; 6: 10 ; 7: 21,23 ; 9: 1 \mathrm{ab}, 2 ; 11: 23 ; 26: 5 ; 27: 2$. 
if two of the major themes of Deuteronomy are taken into account, namely historical reflection and the imminent conquest. Closely linked to this are the number of references to to the Sinai theophany $(5 x),{ }^{34}$ and the wilderness-wanderings $(6 x){ }^{35}$

Taking all of the above into account, it seems that the noun לד̦ in Deut 3:24 is most probably used to refer to "greatness" as an attribute of YHWH, witnessed primarily by Moses (and the people of Israel) in the exodus events, and secondly in the Sinai theophany.

1c Comparison of similar usages of לִ̦ in the Hebrew Bible

As indicated above, the noun section, the eight occurrences of the noun outside the book of Deuteronomy are briefly investigated in order to determine whether these occurrences shed some light on the use of the noun in Deut 3:24.

Closer investigation reveals that these eight occurrences of לָ̧ are used to refer to either God, man or nations. When used to refer to man, it refers to his arrogance (Isa 9:8; 10:12). When used to refer to nations, it refers to the splendour of Egypt and Assyria (Ezek 31:2, 7, 18). When used to refer to God, it is used in the following manners:

- As an attribute of God: In Ps 150:2, the psalmist calls on everything to

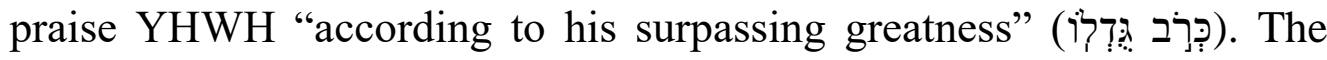
noun without any specific background like the exodus events.

- Adjectivally to emphasise another attribute of God: Twice the noun לד̦

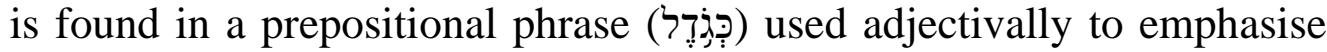
another attribute of God, namely "the greatness of" his "steadfast love"

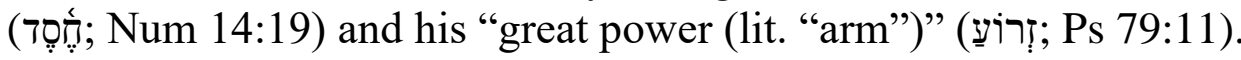

1d Conclusion: לד̦ in in Deut 3:24

In conclusion, the noun לד̦ג in Deut 3:24 most probably refers to "greatness" as an attribute of YHWH. The nuance of the noun here is not so much on what YHWH does (like some occurrences of the adjective לitą in Deuteronomy), but rather on who YHWH is. He is "great."

34 Deuteronomy 4:36; 5:22, 24, 25; 18:16.

35 Deuteronomy 1:19, 28ab; 2:7, 10; 8:15. 


\section{2 ירז הָחָזָקָה ("mighty hand")}

2a Overview of the occurrence and use of ידז ידז in the Hebrew Bible

Occurring more than 1600 times, the noun ד্ণ is one of the most common words used in the Hebrew Bible. ${ }^{36}$ In the book of Deuteronomy alone, it is found 82 times. $^{37}$

In the majority of cases, ? refers to the human hand. ${ }^{38}$ Although a number of secondary or expanded usages of ?ִ יָ are quite common in the Hebrew Bible, ${ }^{39}$ the second most general usage of $\tau_{\tau}$ is where the noun is used figuratively to refer to "power" or "strength." In this regard, דיָ "often stands for a person's power or capacity to rule over others" or "to exercise force." 40

Strikingly, the noun T⿱宀 is found more than 200 times in the Hebrew Bible in reference to God. Used anthropomorphically, the "hand" of God is used mainly to refer to his "power" and "might." 41 References to God's "power" or "might" are found in contexts that refer to his acts in creation, his maintenance of the world, his salvation and his judgment. ${ }^{42}$ The greatest concentration of references to God's power, however, are found in texts that refer to his redemption of his people from Egypt. ${ }^{43}$ In fact, Dreytza argues that the "theological metaphor of God's hand... seems to have its roots in Israel's experience of God redeeming them from slavery in Egypt" [my emphasis, A.J.C.], ${ }^{44}$ although Van der Woude rightly questions this. ${ }^{45}$ Nonetheless, references to God's hand is closely linked to the exodus events.

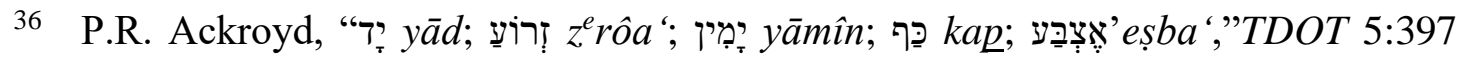
refers to a relative number by stating the יזָ "occurs more than 1600 times" in the

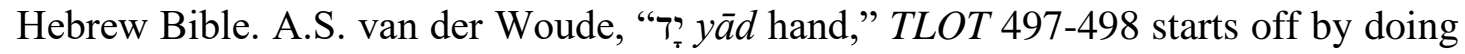
the same (he states that יד has "over 1,600 occurrences" in the Hebrew Bible), but later ventures to give an exact count of 1618 . M. Dreytza, "דיז $(y \bar{a} d)$, hand, power, side," NIDOTTE 2:402 is somewhat more specific, referring to "some 1,617 occurrences of Tיז " in Hebrew and 17 in Aramaic in the Old Testament.

37 Van der Woude, TLOT 498 indicates that $\tau_{\tau}$ appears $71 \mathrm{x}$ in the singular in Deuteronomy and $12 \mathrm{x}$ as dual, which makes a total of 83 occurrences. According to my count, the noun appears $82 \mathrm{x}$ in Deuteronomy.

38 Cf. Van der Woude, TLOT 499; Dreytza, NIDOTTE 2:402; Ackroyd, TDOT 5:400.

39 Cf. Van der Woude, TLOT 499 and Ackroyd, TDOT 5:400-403.

40 Van der Woude, TLOT 500.

41 God's "hand" is also used in other ways. See Dreytza, NIDOTTE 2:403-404 and Van der Woude, TLOT 501-502 for further details.

42 Cf. Van der Woude, TLOT 501.

43 Ibid., 501-502.

44 Dreytza, NIDOTTE 2:403. 


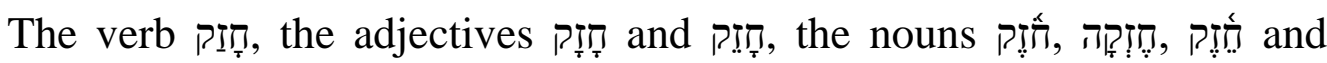
חָז derived from the root Tr. The root and all its derivatives have the basic meaning of "be/become strong."

The adjective "has a variety of meanings, depending on the context," being or becoming "strong" or "mighty." 49 It is mostly used in reference to men (individually or collectively) or anthropomorphically to God, and in reference to bodily strength. ${ }^{50}$

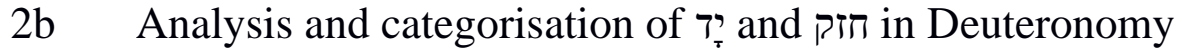

A closer look at the 82 occurrences of the noun in Deuteronomy reveals that while the majority of references to Tr in Deuteronomy refers to various concepts linked to or derived from the hand of man $( \pm 79 \%)$, a sizeable amount of references refers to the hand of God $( \pm 18 \%)$. The results of this investigation can be seen in Table 3 .

\begin{tabular}{|c|c|c|}
\hline Hand of God & $15 x$ & $\begin{array}{l}2: 15 ; 3: 24 ; 4: 34 ; 5: 15 ; 6: 21 ; 7: 8,19 ; 9: 26 ; 11: 2 ; 26: 8 \\
32: 39,40,41 ; 33: 3,7\end{array}$ \\
\hline Hand of man & $65 x$ & $\begin{array}{l}1: 25,27 ; 2: 7,24,30 ; 3: 2,3,8 ; 4: 28 ; 6: 8 ; 7: 8,24 ; 8: 17 \\
9: 15,17 ; 10: 3 ; 11: 18 ; 12: 6,7,11,17,18 ; 13: 10^{2}, 18 ; \\
14: 25,29 ; 15: 2,3,7,8,10,11 ; 16: 10,15,17 ; 17: 7^{2} ; 19: 5 \text {, } \\
12,21 ; 20: 13 ; 21: 6,7,10 ; 23: 21,26 ; 24: 1,3,19 ; 25: 11^{2} ; \\
26: 4 ; 27: 15 ; 28: 8,12,20,32 ; 30: 9 ; 31: 29 ; 32: 27,36 ; \\
33: 11 ; 34: 9,12\end{array}$ \\
\hline Object & $2 x$ & $2: 37 ; 23: 13$ \\
\hline
\end{tabular}

Table 3: Subject of Tיז in Deuteronomy

45 Van der Woude, TLOT 501 correctly argues that references to the hand of God is "prefigured" in other Semitic expressions, and that it is therefore "questionable whether the strong emphasis of language concerning Yahweh's hand (and arm) derived impetus from the exodus narratives."

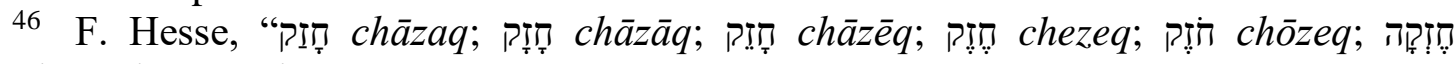
chezqāh; i⿱艹 chozqāh," TDOT 4:301.

47 This count is supported by Hesse, TDOT 4:301 and A.S. van der Woude, "ח hzq to be firm," TLOT 404. R. Wakely, "קזָ ḩazaq," NIDOTTE 2:64 is more tentative by stating that the adjective is found 56 or 57 times in the Hebrew Bible.

48 Wakely, NIDOTTE 2:79.

49 Cf. Brown, Driver and Briggs, Enhanced Lexicon, 305.2.

50 Hesse, TDOT 4:302, 305. 
The 15 references to God's hand are all used in a single fashion; all of them refer to the "might" or "power" of God. This is mainly expressed anthropomorphically in the phrase "the mighty hand" of God (two-thirds of the

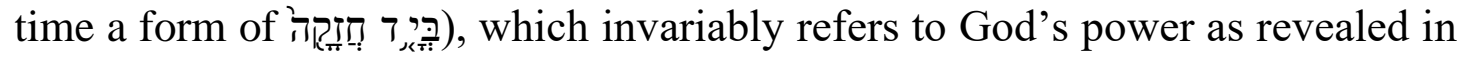
the exodus from Egypt $(3: 24 ; 4: 34 ; 5: 15 ; 6: 21 ; 7: 8,19 ; 9: 26 ; 11: 2 ; 26: 8)$. References to God's "hand" are also found without the coupling with the adjective "mighty" to refer to his judgment $(2: 15 ; 32: 41)$, omnipotence $(32: 39)$, trustworthiness (32:40) and protection $(33: 3,7)$.

To the 15 references to God's hand referring to his power can be added eight references to YHWH giving someone over into the "hand" of someone else $(1: 27 ; 2: 24,30 ; 3: 2,3 ; 7: 24 ; 20: 13 ; 21: 10)$. The phrase, which consists of the noun is in combination with the verb express the concept of delivering someone into someone else's power.

The verb $25: 11 ; 31: 6,7,23)$, but never with God as subject. The adjective ten times in Deuteronomy, and strikingly, always within the phrase הִדְזָזָה ("mighty hand"). Nine of the ten occurrences of חָז in Deuteronomy refer to God's "mighty hand," all of which have the exodus event as background (3:24; $4: 34 ; 5: 15 ; 6: 21 ; 7: 8,19 ; 9: 26 ; 11: 2 ; 26: 8)$. The only exception in this regard is Deut 34:12, which, upon closer inspection, is no exception at all. Although it explicitly mentions Moses' "mighty hand," it refers to Moses' agency in the exodus events as enabled by YHWH. By implication, Moses' "mighty hand" can indirectly be interpreted as God's "mighty hand."

\section{2c Comparison of similar usages of יד החדזָזָה in the Hebrew Bible}

References to the "strong" or "mighty" hand of man or God are quite common in the Hebrew Bible. In fact, 28 of the 56 occurrences of Bible are found in combination with "hand," as can be seen in Table 4.

\begin{tabular}{|c|c|c|}
\hline דָד wזָזָק with & $28 x$ & $\begin{array}{l}\text { Exod } 3: 19 ; 6: 1^{2} ; 13: 9 ; 32: 11 ; \text { Num 20:20; } \\
\text { Deut 3:24; 4:34; 5:15; 6:21; 7:8, 19; 9:26; 11:2; } \\
\text { 26:8; 34:12; Josh 4:24; } 1 \text { Kgs 8:42; Jer 21:5; } \\
\text { 31:11; 32:21; Ezek 20:33,34; Ps 136:12; Job 5:15; } \\
\text { Dan 9:15; Neh 1:10; } 2 \text { Chron 6:32 }\end{array}$ \\
\hline $\begin{array}{l}\text { Other occurrences } \\
\text { of חָזָ }\end{array}$ & $28 x$ & $\begin{array}{l}\text { Exod 10:19; 19:16; Num 13:18, 31; Josh 14:11; } \\
\text { 17:18; Judg 18:26; } 1 \text { Sam 14:52; } 2 \text { Sam 11:15; } \\
\text { 1 Kgs 17:17; 18:2; 19:11; Isa 27:1; 28:2; 40:10; } \\
\text { Jer 50:34; Ezek 2:4; 3:7, 82, 9; 26:17; 30:22; } \\
\text { 34:16; Amos 2:14; Ps 35:10; Job 37:18; Prov } \\
\text { 23:11 }\end{array}$ \\
\hline
\end{tabular}

Table 4: Occurrence of חָזָ in the Hebrew Bible 
Although ambiguity in some contexts makes an exact number difficult, it seems that of the 28 occurrences of in combination with $\pi_{\tau}$, at least 22 refer to the mighty hand of God. A breakdown of this can be seen in Table 5 below.

\begin{tabular}{|l|l|l|}
\hline Mighty hand of God & $22 x$ & $\begin{array}{l}\text { Exod 13:9; 32:11; Deut 3:24; 4:34; 5:15; 6:21; } \\
\text { 7:8, 19; 9:26; 11:2; 26:8; 34:12; Josh 4:24; 1 } \\
\text { Kgs 8:42; Jer 21:5; 32:21; Ezek 20:33,34; } \\
\text { Ps 136:12; Dan 9:15; Neh 1:10; 2 Chron 6:32 }\end{array}$ \\
\hline Mighty hand of man & 5x & Exod 6:12; Num 20:20; Jer 31:11; Job 5:15 \\
\hline Ambiguous/uncertain & $1 \mathrm{x}$ & Exod 3:19 \\
\hline
\end{tabular}

Table 5: Subject of occurrences of חָזָ in combination with iִ in the Hebrew Bible

To this count should be added other derivatives of nin combination

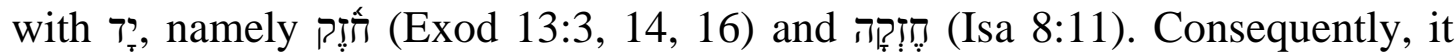
seems that there are 26 references to God's "mighty hand" in the Hebrew Bible. Viewing these references together, the following becomes clear:

- The "mighty hand" of God emphasises YHWH's superiority. ${ }^{52}$

- About three quarters of the references to God's "mighty hand" have the exodus from Egypt as backdrop. This is the case with probably 19 of the 26 references $( \pm 73 \%){ }^{53}$ The assumption that the phrase "the mighty hand" of God refers primarily to YHWH's deliverance of Israel from Egypt $^{54}$ is therefore proven. To this can be added the intriguing hypothesis of Hoffmeier, who argues that the phrase "mighty hand" may consciously be used polemically in the exodus narratives against the

51 In my view, the presumably ambiguous "mighty hand" references in Exod 6:12 indicated by Hesse, TDOT 4:305 and Wakely, NIDOTTE 2:81 are not convincingly ambiguous. The text seems to refer to the "strong hand" with which Pharaoh would drive the Israelites from Egypt, emphasising his eagerness for them to leave. For an overview of different views, see Wakely, NIDOTTE 2:81. The only truly ambiguous

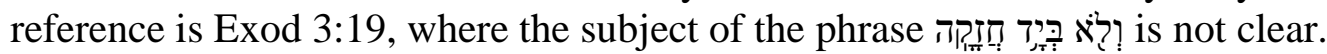

52 Hesse, TDOT 4:305.

53 Exod 13:3, 9, 14, 16; 32:11; Deut 3:24; 4:34; 5:15; 6:21; 7:8, 19; 9:26; 11:2; 26:8; 34:12; Josh 4:24; Jer 32:21; Ps 136:12; Dan 9:15.

54 See Brown, Driver and Briggs, Enhanced Lexicon, 305.2; Van der Woude, TLOT 405; Wakely, NIDOTTE 2:81. 
Egyptian concept of the "mighty" or "conquering hand" (arm) of Pharaoh. ${ }^{55}$ It is not Pharaoh who is god and king; YHWH is.

- All the references to God's "mighty hand" in the Pentateuch refer to the exodus from Egypt. Those outside the Pentateuch may refer to this as well, but it is not always the case. Strikingly, a number of references are used to refer to the return from exile (Neh 1:10; Ezek 20:34), which can be viewed as modelled on the original salvific act, namely the exodus.

- References to God's "mighty hand" is often coupled with other words or concepts, ${ }^{56}$ as is the case in Deut 3:24. This includes the following: "greatness" (Deut 3:24; 9:26; 11:2), "works/deeds" (Deut 3:24; 11:2-3), "trials" (Deut 4:34; 7:19), "signs" (Deut 4:34; 6:21-22; 7:19; 11:2-3; 26:8; Jer 32:21), "wonders" (Deut 4:34; 6:21-22; 7:19; 26:8; Jer 32:21), "outstretched arm" (Deut 4:34; 5:15; 7:19; 11:2; 26:8; $1 \mathrm{Kgs}$ 8:42; Jer 32:21; Ezek 20:33, 34; Ps 136:12; 2 Chron 6:32), “(a) terrifying display(s) of power" (lit. "great [deeds of] terror"; Deut 4:34; 26:8; 34:12; Jer 32:21), and "(great) wrath" (Jer 21:5; Ezek 20:33, 34).

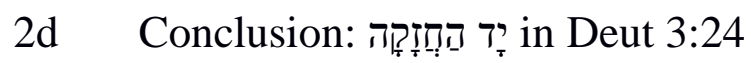

Taking all of the above into consideration, it becomes clear that the reference to

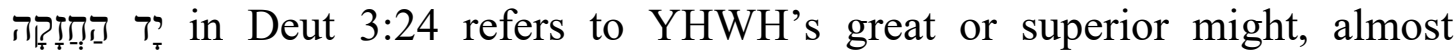
certainly as revealed, demonstrated, or expressed in the exodus events. Placed

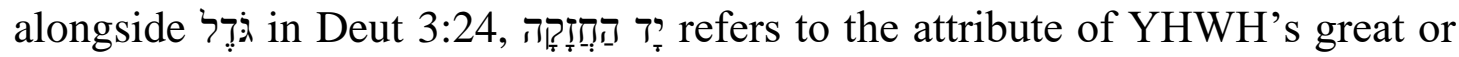
superior might.

\section{3 ("deeds")}

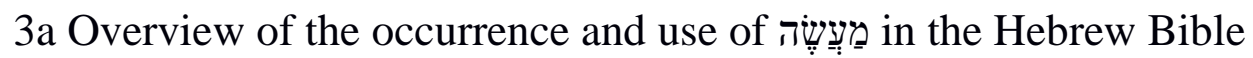

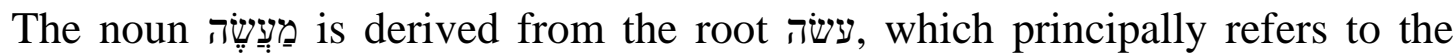
action "to make" or "to do." The verb עָ עָ is found approximately 2627 times in the Hebrew Bible, ${ }^{58}$ which makes it "the third most common verb in the OT." ${ }^{59}$

55 James K. Hoffmeier, "The Arm of God versus the Arm of Pharaoh in the Exodus Narratives," Bib 67/3 (1986): 386.

56 Cf. Wakely, NIDOTTE 2:81 and Hesse, TDOT 4:305.

57 Jeremiah 21:5 is unique in the sense that it mixes the usual nouns and adjectives. It refers to the "outstretched hand" and "strong arm" of YHWH.

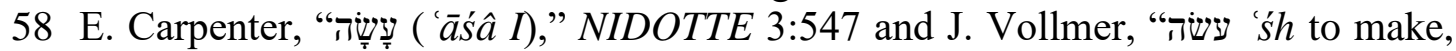

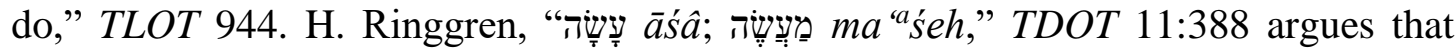
"[e]tymological uncertainty makes it impossible to state the number of occurrences precisely."

59 Vollmer, TLOT 944. 
As could be expected of such a common verb, "[t] $]$ he semantic field of" "is very large, the range of nuances extraordinarily broad." in the qal the verb "conforms pretty much to the meanings to make or to do, with many nuances of each of these meanings employed." ${ }_{61}$

When used in a theological sense, the verb עָשָ refers to YHWH's action in all realms. The verb is used to refer to his activity and control over history, nature and people, ${ }^{62}$ or put differently, to his activity "at a national, universal, or personal level." "63 The verb עָשָׁ is also "the most general word used to describe" God's "creative acts." ${ }^{64}$ The use of the verb in reference to God's activity in history includes all major national events, including the exodus from Egypt and the exile, ${ }^{65}$ as well as specific events in the lives of individuals.

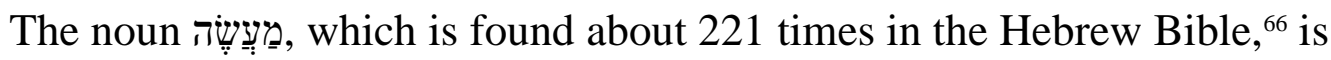
a "noun of action of the verb עָָָָׁ", namely "that which any one makes or does." ${ }^{\prime 7}$ Consequently, it mostly refers to a "work", "deed," "action," "act" or a variety of handiworks or products, of both man and God. ${ }^{68}$ When used to refer to man's deeds or work, it often has an ethical connotation. ${ }^{69}$ When used for the works of God, it can refer to his governance in history and divine providence in creation. ${ }^{70}$

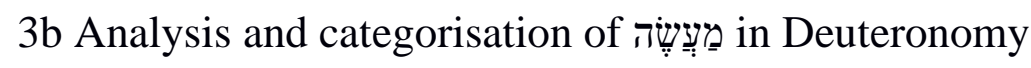

The verb עָ עָ is found 160 times in Deuteronomy. ${ }^{71}$ Since the meaning and use of the verb is extremely broad and context-specific, it does not seem fruitful to classify and categorise the occurrences of the verb in Deuteronomy. Since the aim of this study is to investigate the meaning of investigation that follows will focus on the meaning and occurrence of the noun

60 Ibid., 945. Cf. Ringgren, TDOT 11:388.

61 Carpenter, NIDOTTE 3:547.

62 Vollmer, TLOT 949-950. Cf. Ringgren, TDOT 11:392.

63 Carpenter, NIDOTTE 3:550.

64 Ibid., 3:547. Cf. Ringgren, TDOT 11:390 and Vollmer, TLOT 949.

65 See Ringgren, TDOT 11:396-397 for the verb in connection to YHWH's acts in history, as expressed especially in exilic and postexilic literature.

66 Vollmer, TLOT 945 gives the exact count as 235, while Carpenter, NIDOTTE 3:547, states that the noun is found 220 to 236 times in the Hebrew Bible. Counting the references in Lisowsky, Konkordanz, 843-844, results in a total of 221.

67 Gesenius and Tregelles, Hebrew and Chaldee Lexicon, 497. Cf. Ringgren, TDOT 11:399.

68 Cf. Brown, Driver and Briggs, Enhanced Lexicon, 795.2.

69 Vollmer, TLOT 948.

70 Ringgren, TDOT 11:401-402.

71 Vollmer, TLOT 945. 
in Deuteronomy. It should be noted, however, that the verb עָָָ is used in

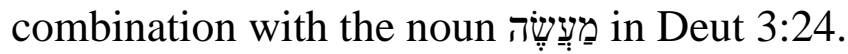

The noun מַעִ in found 13 times in Deuteronomy. A closer look at these 13 occurrences reveal that the noun is mainly used in three ways, of which a summary can be seen in Table 6 .

\begin{tabular}{|l|l|l|}
\hline Israel's daily labour & $8 \mathrm{x}$ & $\begin{array}{l}2: 7 ; 14: 29 ; 15: 10 ; 16: 15 ; 24: 19 ; 28: 12 ; 30: 9 ; \\
31: 29\end{array}$ \\
\hline The production of idols & $2 \mathrm{x}$ & $4: 28 ; 27: 15$ \\
\hline YHWH's work in history & $3 \mathrm{x}$ & $3: 24 ; 11: 3,7$ \\
\hline
\end{tabular}

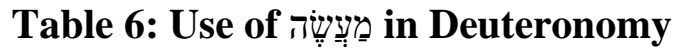

In three occurrences in Deuteronomy, the noun מַעְע refers to YHWH's work in history. Apart from Deut 3:24, the noun is found twice in Deut 11 to refer to God's activity during the exodus-Israel is called to reflect on YHWH's acts during the exodus (11:3), and also on all his acts since (and including) the exodus up to the specific point in time that Moses directs the words of Deuteronomy to them (11:7). Forming a parallel with Deut 3:24, God's acts in history are linked in Deut 11:3 to his "discipline," "greatness, "mighty hand and outstretched arm" and "signs." Consequently, it seems that the noun in Deut 3:24 could be interpreted as YHWH's deeds in history, specifically, during the exodus.

3c Comparison of similar usages of in the Hebrew Bible

Based on the 221 occurrences of the noun in the Hebrew Bible identified by Lisowsky, ${ }^{72}$ a survey reveals that the noun is mostly used to refer to the "works" or "deeds" of man, or derivatives associated with man $( \pm 70 \%$ of all occurrences). In almost a quarter of the occurrences (53 of the $221[ \pm 24 \%]$ ), however, the noun is used in reference to God. An overview of the different usages of the noun in reference to God can be seen in Table 7 .

72 Lisowsky, Konkordanz, 843-844. 


\begin{tabular}{|l|l|l|}
\hline Deeds of God in general & $19 x$ & $\begin{array}{l}\text { Isa } 5: 12 ; \text { Pss } 28: 5 ; 33: 4 ; 66: 3 ; 86: 8 ; 92: 5,6 ; \\
104: 13 ; 107: 22 ; 111: 2,7 ; 118: 17 ; 143: 5 ; \\
145: 4,17 ; \text { Eccl } 3: 11 ; 7: 13 ; 8: 17 ; 11: 5\end{array}$ \\
\hline Specific deeds of God & $7 x$ & $\begin{array}{l}\text { Exod } 34: 10 ; \text { Josh } 24: 31 ; \text { Judg } 2: 7,10 ; \text { Jer } \\
51: 10 ; \text { Pss } 106: 13 ; 111: 6\end{array}$ \\
\hline God's creation & $11 x$ & $\begin{array}{l}\text { Pss } 8: 4,7 ; 19: 2 ; 102: 26 ; 103: 22 ; 104: 24,31 ; \\
107: 24 ; 139: 14 ; 145: 9,10\end{array}$ \\
\hline People as God's work & $8 x$ & $\begin{array}{l}\text { Isa } 19: 25 ; 29: 23 ; 60: 21 ; 64: 7 ; \text { Ps } 138: 8 ; \\
\text { Job } 14: 15 ; 34: 19 ; 37: 7\end{array}$ \\
\hline God's judgment & $6 x$ & Isa 5:19; $10: 12 ; 28: 212 ;$ Ps 64:10; Dan 9:14 \\
\hline Objects & $2 x$ & Exod 32:16; Prov 16:11 \\
\hline
\end{tabular}

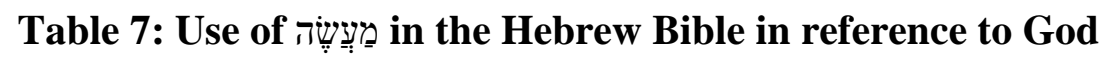

From the above it becomes clear that the noun מַעְעשֶׁה is often used to refer to the deeds of God in general (including references to his providence and nonspecific references to his deeds in history) and God's creation. Of importance for this study are the occurrences where the noun refers to specific deeds of God within Israel's history, as seems to be the case in Deut 3:24. An overview of the specific events referred to in these cases is found in Table 8 below.

\begin{tabular}{|l|l|}
\hline Exod 34:10 & Events during the wilderness years and the conquest \\
\hline Josh 24:31 & Events from the exodus to the division of the Promised Land \\
\hline Judg 2:7,10 & Events from the exodus to the division of the Promised Land \\
\hline Jer 51:10 & Events associated with the deliverance from exile \\
\hline Ps 106:13 & The exodus events, especially, at the Red Sea \\
\hline Ps 111:6 & Events associated with the conquest \\
\hline
\end{tabular}

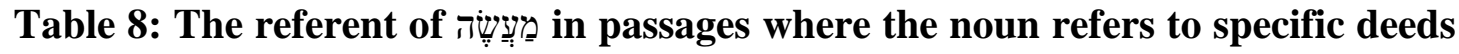
of God within Israel's history

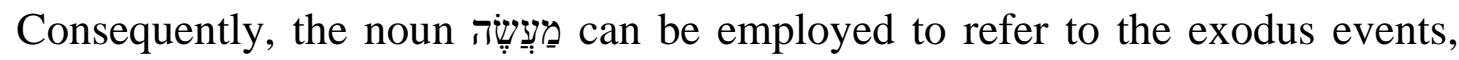
the wilderness period, the conquering and division of the Promised Land and the deliverance from exile. The possibility of interpreting מַעִשֶֶׁ in Deut 3:24 as YHWH's work in the exodus events, or even from the exodus up to the point where Moses prays the words of Deut 3:24, seems justified. 


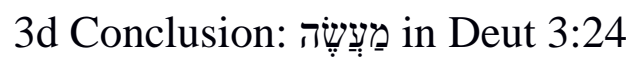

Taking all of the above into consideration, מַעְשָׁ in Deut 3:24 seems to refer to YHWH's deeds in history, especially, as witnessed in the exodus events (and possibly subsequent events up to the time just prior to the conquest of the Promised Land). This is strengthened by the fact that the verb עָ is used in

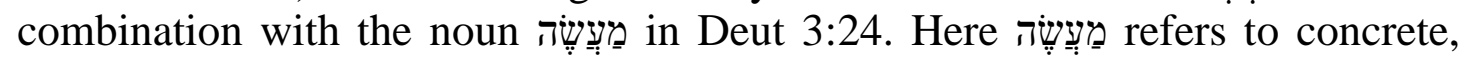
visible and perceptible deeds that YHWH has done.

\section{4 ("mighty acts")}

4a Overview of the occurrence and use of גבר in the Hebrew Bible

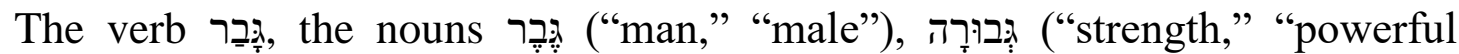

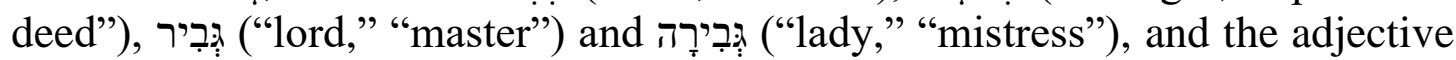

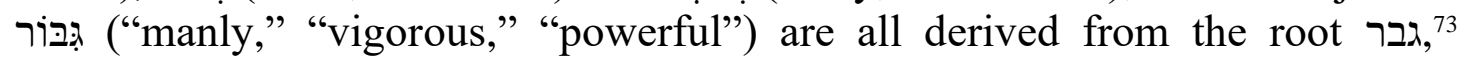
which has the basic meaning of "to be superior" or "to be strong." "74

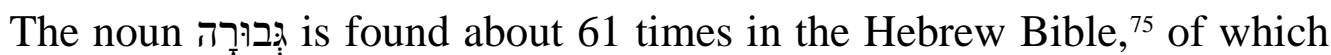
11 are in the plural form. ${ }^{76}$ The basic meaning of the noun is closely related to the verb, and can be rendered as "superiority," "strength," "might" or "power." ${ }^{\prime 7}$ It is used to refer to the physical strength of animals and man, ${ }^{78}$ and often refers to military might..$^{79}$ The noun can also refer to "ability" in the more general sense,$^{80}$ or to man's spiritual strength, which is linked to his power, wisdom and understanding. ${ }^{81}$ The word is also employed to refer to God's

73 V.P. Hamilton, "הֶּר (geber I)," NIDOTTE 1:816, however, states that it is not

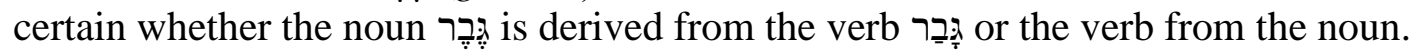

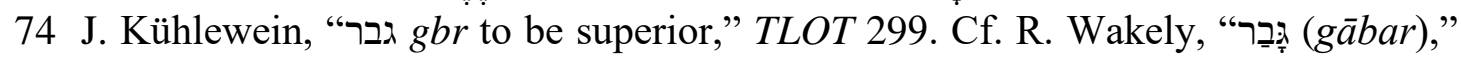
NIDOTTE 1:806.

75 Kühlewein, TLOT 299 and Lisowsky, Konkordanz, 304-305 count 61 occurrences,

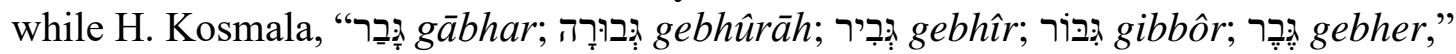
TDOT 2:367 counts 64. My own investigation led to the same references and count as Lisowsky's.

76 Namely הִּוּרוּרת. Cf. Deut 3:24; Isa 63:15; Pss 20:7; 71:16; 90:10; 106:2; 145:4, 12; 150:2; Job 26:14; 41:4. According to Kosmala, TDOT 2:372, in all but one of these passages (Ps 90:10) גבוּרוּרת , refers to the great acts of God, but this is challenged below. In my view, only nine of these occurrences refer explicitly to God's power (Job 41:4 refers to the power of the Leviathan, and indirectly to God's power), and only about half refer to his mighty "deeds."

77 Kühlewein, TLOT 300. Cf. Brown, Driver and Briggs, Enhanced Lexicon, 150.12.

78 Kosmala, TDOT 2:369.

79 Kühlewein, TLOT 300. Cf. Gesenius and Tregelles, Hebrew and Chaldee Lexicon, 154.

80 Kühlewein, TLOT 300.

81 Kosmala, TDOT 2:371-372. 
power and ethical strength, especially in connection with his justice, righteousness, grace, faithfulness, wisdom and understanding. ${ }^{82}$ In the Rabbinic age (as reflected in Rabbinic literature), when the name YHWH was no longer uttered, the noun was used "as a substitute for the proper name of God." ${ }^{83}$

4b גבר Analysis and categorisation outeronomy

Analysing and categorising the root גבר in Deuteronomy does not produce

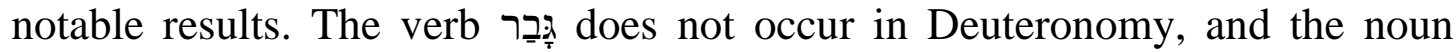

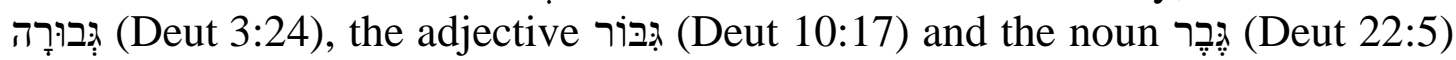
occur once each. Excluding the occurrence in Deut 3:24, the only real

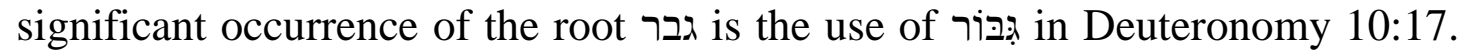
Just like Deut 3:24, Deut 10:17 emphasises YHWH's uniqueness and describes

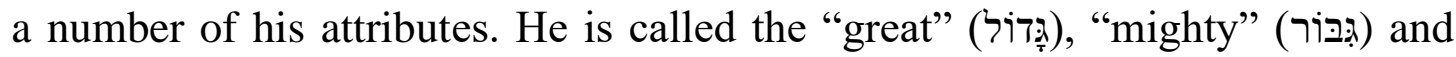
"awesome" (יריז (ירא) God.

In the light of the scarcity of data in Deuteronomy, an analysis and categorisation of all occurrences of בְברוּרָ in the Hebrew Bible will be subsequently done.

4c Analysis and categorisation of

As indicated above, the noun aִּרוּרָ is found 61 times in the Hebrew Bible. A closer look reveals that it is mainly used in four ways, as can be seen in Table 9 below.

\begin{tabular}{|c|c|c|}
\hline Of man & $31 x$ & $\begin{array}{l}\text { Exod 32:18; Judg 8:21; } 1 \text { Kgs } 15: 23 ; 16: 5,27 ; \\
\text { 22:46; } 2 \text { Kgs 10:34; } 13: 8,12 ; 14: 15,28 ; 18: 20 ; \\
\text { 20:20; Isa 3:25; 11:2; 28:6; 30:15; 36:5; Jer 9:22; } \\
\text { 23:10; 49:35; 51:30; Ezek 32:29, 30; Mic 3:8; 7:16; } \\
\text { Ps 90:10; Eccl 9:16; 10:17; Est 10:2; } 1 \text { Chron 29:30 }\end{array}$ \\
\hline Of God & $25 x$ & $\begin{array}{l}\text { Deut } 3: 24 ; \text { Isa } 33: 13 ; 63: 15 ; \text { Jer } 10: 6 ; 16: 21 ; \\
\text { Pss } 20: 7 ; 21: 14 ; 54: 3 ; 65: 7 ; 66: 7 ; 71: 16,18 ; 80: 3 ; \\
\text { 89:14; 106:2 ,8; 145:4,11, 12; } 150: 2 ; \text { Job 12:13; } \\
\text { 26:14; } 1 \text { Chron 29:11,12; } 2 \text { Chron } 20: 6\end{array}$ \\
\hline Of creation/creatures & $4 \mathrm{x}$ & Judg 5:31; Ps 147:10; Job 39:19; 41:4 \\
\hline For personification & $1 \mathrm{x}$ & Prov 8:14 \\
\hline
\end{tabular}

Table 9: Use of

82 Ibid., 2:369-370.

83 Ibid., 2:370-371. 
A closer investigation of the 25 occurrences of the noun גְִּוּר to refer to the power or might of God reveals that it is mostly found in poetic texts (especially the Psalms, with 15 of the 25 occurrences [60\%]), where the noun is employed to refer to the being of God (Pss 66:7; 89:14; Job 12:13) ${ }^{84}$ his awesome power (in general [Pss 21:14; 71:18; 106:8; 145:11; Job 26:14], or as reflected in his deeds [Pss 71:16; 106:2; 145:4,12; 150:2] and in creation [Ps 65:7]), and his unquestionable ability (twice by way of petition) to save (Pss 20:7; 54:3; 80:3). Outside the poetic literature, it is found four times in the prayers of individuals to refer to God's divine might (Deut 3:24; 1 Chron 29:11,12; 2 Chron 20:6), and four times in the prophetic literature to refer to God's awesome power (Isa 33:13; Jer 10:6; 16:21) and his being (Isa 63:15).

For the purpose of this study, the following should be noted concerning the occurrences of גִּבוּרָ as God's "strength" or "might":

- "Might" as divine attribute in prayers: In all four occurrences of the noun in the prayers of individuals, God's "strength" is coupled with other divine attributes (Deut 3:24; 1 Chron 29:11, 12; 2 Chron 20:6). Excluding the reference found in Deut 3:24, all other occurrences of the noun in prayers seem to refer to "might" as an attribute of YHWH, especially his omnipotence and sovereignty. In Deut 3:24, however,

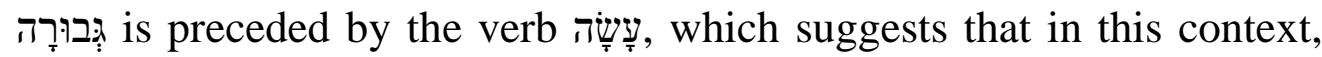
the noun refers to tangible expressions of this attribute.

- YHWH's "might" revealed in the exodus: In Ps 66:7 (see Ps 66:6) and Ps 106:2, 8 (see Ps 106:7-33) YHWH's "might" is linked to the exodus events, which supports the possibility of interpreting the exodus as the background of aִּבוּרָ in Deut 3:24.

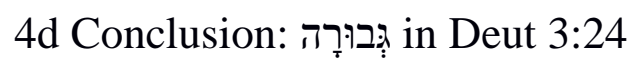

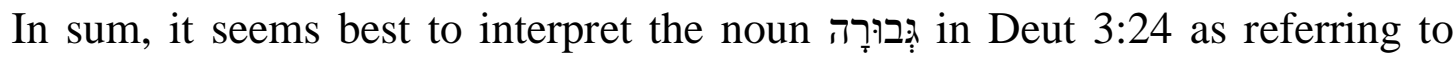
perceptible expressions of YHWH's awesome and surpassing might. This is

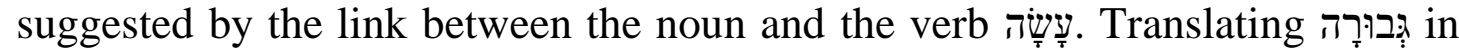
Deut 3:24 as "mighty acts" is therefore fitting. From the above and the context of the passage, these expressions of YHWH's might in Deut 3:24 most probably include (but are not necessarily limited to) the exodus events.

\section{Summary}

In this section, the four words and phrases used in Deut 3:24 to describe the uniqueness of YHWH were investigated in detail in order to distinguish

84 As with the use of the word "attribute," the article takes cognisance of the complex nature of the concept "being" in biblical and philosophical theology. Nonetheless, as with the term "attribute," "being" is used for the sake of discussion. 
between their meanings and to deduce primarily various possibilities of the referential background of each.

Given the conclusions of the previous sections, it seems that a distinction can be made between the first two and last two concepts found in Deut 3:24. While the verb רָָָ ("see") in Deut 3:24 suggests that all four words or phrases refer to concepts that were physically perceptible to Moses, from the above, it seems that the first two refer to attributes of God, namely his "greatness" and "might," while the last two refer to concrete expressions of these attributes, namely his "deeds" and "mighty acts." Put differently, "בְָּ and

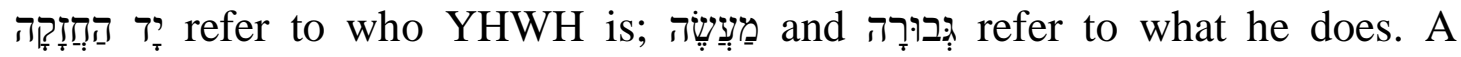
summary of this can be seen in Table 10.

\begin{tabular}{|c|c|}
\hline גָדֶל & "greatness" as attribute of YHWH \\
\hline 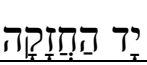 & (superior) "might" as attribute of YHWH \\
\hline מַעַעָשָה & "deeds" as expression of YHWH's attributes \\
\hline 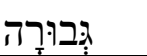 & "mighty acts" as expression of YHWH's attributes \\
\hline
\end{tabular}

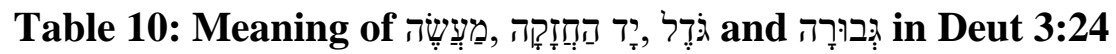

One may be inclined argue that the four items form a chiasm (A greatness; $\mathrm{B}$ might; $\mathrm{B}^{\prime}$ deeds; $\mathrm{A}^{\prime}$ mighty acts) or an $\mathrm{ABAB}$ pattern (at least in English: A greatness; B might; A deeds; B mighty acts), but no convincing evidence for this was found. The conclusion above (arguing that the first two and the last two concepts go together) is supported by the word order in the Hebrew text.

\section{REFERENTIAL BACKGROUND OF WORDS DESCRIBING YHWH IN DEUT 3:24}

In this section, the findings above are synthesised in order to confirm the

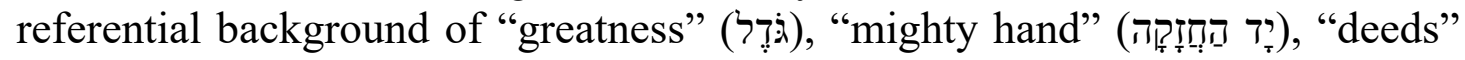

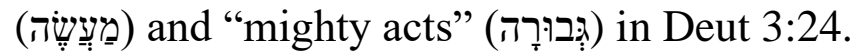

The investigation above found that the exodus events form the most likely referential background of all of these words. Moses witnessed YHWH's "greatness" and "mighty hand" as attributes and his "deeds" and "mighty acts" as concrete expressions of these attributes in everything YHWH did pertaining to Israel's salvation from Egypt. The exodus served as the primary and most dramatic school in which Moses learned who YHWH is and what he does.

While the primacy of the exodus events is undeniable, the investigation above found that the background of these words are not necessarily limited to 
the exodus events. The referential background of these words may include subsequent events up to the time just prior to the conquest of the Promised Land.

These conclusions can be strengthened by tracing the occurrence and use

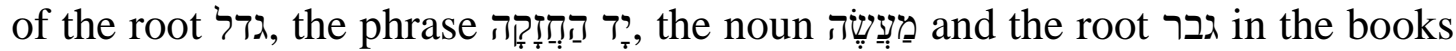
of Exodus to Deuteronomy for specific events linked to them. ${ }^{85}$ The results of this investigation can be seen in Table 11.

\begin{tabular}{|c|c|c|c|c|}
\hline & גדל - גל & 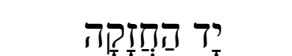 & מַעְשֶׁה & גבר - גבר \\
\hline $\begin{array}{l}\text { Burning } \\
\text { bush }\end{array}$ & Exod 3:3 & & & \\
\hline Exodus & $\begin{array}{l}\text { Exod 6:6; 7:4; } \\
18: 11 ; 32: 11 ; \\
\text { Deut 4:32,34, } \\
37 ; 6: 22 ; 7: 19 ; \\
9: 26,29 ; 10: 21 ; \\
11: 2,7 ; 26: 8 ; \\
29: 2^{2}\end{array}$ & $\begin{array}{l}\text { Exod } 3: 19 ; \\
13: 3,9,14,16 ; \\
32: 11 ; \text { Deut } \\
4: 34 ; 5: 15 ; \\
6: 21 ; 7: 8,19 ; \\
9: 26 ; 11: 2 ; \\
26: 8\end{array}$ & Deut 11:3, 7 & \\
\hline Red Sea & $\begin{array}{l}\text { Exod 14:31; } \\
15: 16\end{array}$ & & & \\
\hline Amalek & & & & $\begin{array}{l}\text { Exod } \\
17: 11^{286}\end{array}$ \\
\hline Sinai & $\begin{array}{l}\text { Deut } 4: 36 ; \\
5: 22,24,25 ; \\
18: 16\end{array}$ & & & \\
\hline Wilderness & $\begin{array}{l}\text { Num 14:17,19; } \\
\text { Deut 11:7 }\end{array}$ & & $\begin{array}{l}\text { Exod 34:10; } \\
\text { Deut 11:7 }\end{array}$ & \\
\hline Conquest & & & Exod 34:10 & \\
\hline
\end{tabular}

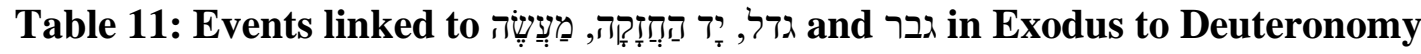

The table above supports the interpretation that Moses' experiences of YHWH's attributes and expressions of these attributes first and foremost refer to the exodus events. Without a doubt, this is the primary referential context.

85 The roots גבר are investigated to broaden the scope of the search.

86 The absence of the root גבל גבר in reference to YHWH's being or conduct in the books of Exodus to Deuteronomy is striking (with the verb in Exod 17:11 being the only possible exception). Cf. Kühlewein, TLOT 301. 
The table, however, also indicates that subsequent events may also be in view. Consequently, it may be that Moses' perception of who YHWH is and what he has done as expressed in Deut 3:24 should not be limited to the exodus events only. The fact that Deut 3:24 does not explicitly refer to a specific referential context may be deliberate to include various (if not all) of Moses' experiences of YHWH's attributes and expressions of these attributes, which would include all the events in his life since his calling up to the point in time where he prays these specific words.

\section{E CONCLUSION}

The preceding discussion will now conclude by reflecting on the distinctive contribution of Deut 3:24 to Deuteronomy's overall theme of the uniqueness of YHWH.

Various references to the uniqueness or incomparability of YHWH are found throughout the book of Deuteronomy (i.e. Deut 4:32-40; 6:4; 7:9; 9:26; $10: 17 ; 11: 2 ; 32: 39 ; 33: 26)$. Of these, the passages that have the most overlap with Deut 3:24 are Deut 9:26, 10:17 and 11:2. Focusing on the content of these references, Deut 11:2-3 forms the closest parallel. While Deut 9:26 uses the

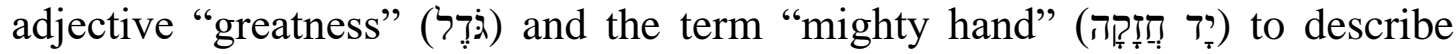

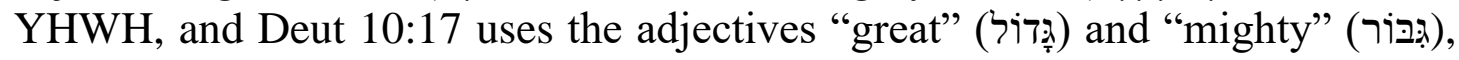

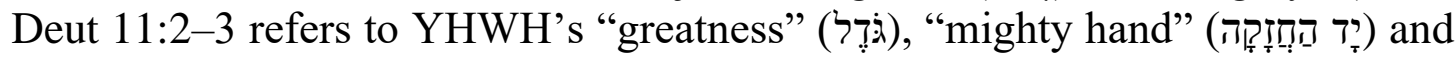

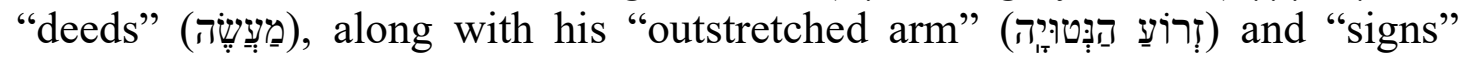
(תiא). Moreover, the exodus events are explicitly stated as the referential background of these words.

When it comes to form, however, Deut 9:26 has the closest parallel to Deut 3:24. Both contain prayers by Moses. In fact, Deut 3:24-25 and 9:26-29 are the only two prayers by Moses found in the book. Moreover, both are

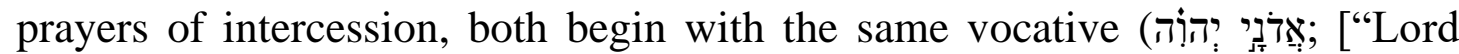
GOD"]), and both start by describing the uniqueness of YHWH. ${ }^{87}$ As such, the words contained in Deut 3:24 and 9:26 are unique in the sense that they reflect Moses' personal convictions concerning YHWH..$^{88}$

In these words, we hear the convictions of the prophet-lawgiver-leader of the Israelites; the man who was called by YHWH to lead his people out of Egypt to the Promised Land; the man who directly witnessed countless expressions of YHWH's being and conduct through forty years of active

87 Weinfeld, Deuteronomy, 191 indicates that beginning a prayer with the uniqueness of YHWH is characteristic of Deuteronomy and the Deuteronomic literature.

88 Craigie, Deuteronomy, 125, fittingly states that this prayer gives us "new insight concerning the nature of" Moses' "relationship with the Lord." 
service. If anyone among the Israelites could have known (as far as is humanly possible) the intricacies of the being and conduct of YHWH, it was Moses.

The difference between Deut 3:24 and 9:26 has to do with both context and those prayed for. While Moses prays for the people in Deut 9:26 after the golden calf incident, ${ }^{89}$ in Deut 3:24 he prays for himself shortly before the conquest of the Promised Land. In Deut 3:24 the 120-year-old Moses grounds his personal prayer for access to the Promised Land in his personal convictions about YHWH. He is convinced that no other god anywhere is like YHWH or can do the things he has done, and that the things he has witnessed are but the beginning of the revelation of who YHWH is and what he can do.

\section{H BIBLIOGRAPHY}

Albertz, Rainer. A History of Israelite Religion in the Old Testament Period. 2 vols. Translated by J. Bowden. London: SCM Press, 1994.

Block, Daniel I. Deuteronomy. The NIV Application Commentary. Grand Rapids: Zondervan, 2012.

Botterweck, G. Johannes and Helmer Ringgren., eds. Theological Dictionary of the Old Testament. 15 Vols. Translated by John T. Willis. Grand Rapids: Eerdmans, 1975-2015.

Brown, Francis, Samuel R. Driver and Charles A. Briggs. Enhanced Brown-DriverBriggs Hebrew and English Lexicon. Oxford: Clarendon Press, 1977.

Brueggemann, Walter. Theology of the Old Testament: Testimony, Dispute, Advocacy. Minneapolis: Fortress Press, 1997.

Brueggemann, Walter. Deuteronomy. Abingdon Old Testament Commentaries. Nashville: Abingdon Press, 2001.

Christensen, Duane L. Deuteronomy 1:1-21:9. Word Biblical Commentary. Nashville: Thomas Nelson Publishers, 2001.

Coetsee, Albert. "YHWH and Israel in Terms of the Concept of Life in Deuteronomy." Old Testament Essays 32/1 (2019): 101-126.

Craigie, Peter C. The Book of Deuteronomy. New International Commentary on the Old Testament. Grand Rapids: Eerdmans, 1976.

Gesenius, F.H. Wilhelm and Samuel P. Tregelles. Gesenius' Hebrew and Chaldee Lexicon to the Old Testament Scriptures. Bellingham: Logos Bible Software, 2003.

Goldingay, John. Old Testament Theology. 3 vols. Downers Grove: Intervarsity Press, 2003-2009.

Hoffmeier, James K. "The Arm of God versus the Arm of Pharaoh in the Exodus Narratives." Biblica 67/3 (1986): 378-387.

Jenni, Ernst and Claus Westermann, eds. Theological Lexicon of the Old Testament. 3 Vols. Translated by Mark E. Biddle. Peabody: Hendrickson Publishers, 1997.

89 Although the context of the prayer seems to be at first glance the rebellion of the people at Kadesh-barnea (cf. Deut 9:23), closer investigation reveals that it refers to Moses' first intercession for the people on Mount Sinai after the golden calf incident (cf. Exod 32:11-14). See Lundbom, Deuteronomy, 374 and Block, Deuteronomy, 257. 
Labuschagne, Casper. J. The Incomparability of Yahweh in the Old Testament. Leiden: Brill, 1966.

Lisowsky, Gerhard. Konkordanz zum Hebräischen Alten Testament. Stuttgart: Privilegierte württembergische Bibelanstalt, 1958.

Lundbom, Jack R. Deuteronomy: A Commentary. Grand Rapids: Eerdmans, 2013.

MacDonald, Nathan. Deuteronomy and the Meaning of Monotheism. 2nd ed. Tübingen: Mohr Siebeck, 2012.

Mann, Thomas. W. "Theological Reflections on the Denial of Moses." Journal of Biblical Literature 98/4 (1979): 481-494.

McConville, J. Gordon. Deuteronomy. Apollos Old Testament Commentary. Leicester: Apollos, 2002.

Merrill, Eugene H. Deuteronomy. The New American Commentary. Nashville: Broadman \& Holman, 1994.

O'Kennedy, Daniël F. "Prayer in Moab (Dt 3:23-29): The Relationship between the Recorded Prayer and Its Historical Geographical Setting." Old Testament Essays 11/2 (1998): 288-305.

Otto, Eckart. Deuteronomium 1,1-4,43. Herders Theologischer Kommentar zum Alten Testament. Freiburg im Breisgau: Herder, 2012.

Tigay, Jeffrey H. The JPS Torah Commentary: Deuteronomy. Philadelphia: Jewish Publication Society, 1996.

VanGemeren, Willem A., ed. New International Dictionary of Old Testament Theology and Exegesis. 5 Vols. Grand Rapids: Zondervan, 1997.

Weinfeld, Moshe. Deuteronomy 1-11. Anchor Bible. New York: Doubleday, 1991.

Wright, Christopher J.H. Deuteronomy. New International Biblical Commentary. Peabody: Hendrickson Publishers, 1996.

Dr. Albert Coetsee, School for Christian Ministry and Leadership, North-West University. Email: albert.coetsee @nwu.ac.za. ORCID: https://orcid.org/0000$\underline{0002-5549-2474}$ 